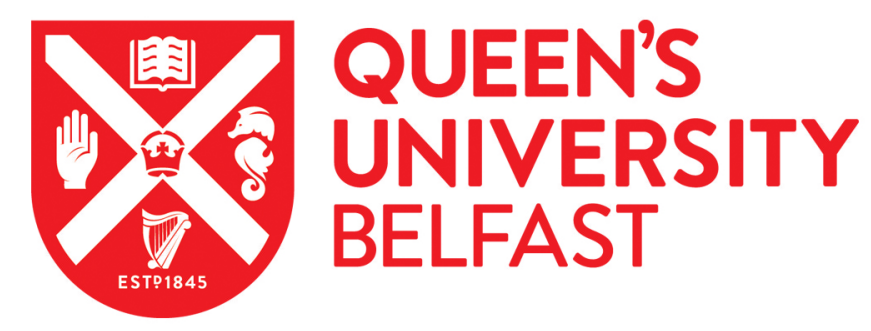

\title{
Response to Morley: The Influence of Climate on Survival of Paramphistome Metacercariae.
}

Huson, K., Oliver, N., \& Robinson, M. (2017). Response to Morley: The Influence of Climate on Survival of Paramphistome Metacercariae. Trends in Parasitology. https://doi.org/10.1016/j.pt.2017.10.006

\section{Published in:}

Trends in Parasitology

\section{Document Version:}

Peer reviewed version

Queen's University Belfast - Research Portal:

Link to publication record in Queen's University Belfast Research Portal

Publisher rights

(c) 2017 Elsevier Ltd. All rights reserved. This work is made available online in accordance with the publisher's policies. Please refer to any applicable terms of use of the publisher

\section{General rights}

Copyright for the publications made accessible via the Queen's University Belfast Research Portal is retained by the author(s) and / or other copyright owners and it is a condition of accessing these publications that users recognise and abide by the legal requirements associated with these rights.

Take down policy

The Research Portal is Queen's institutional repository that provides access to Queen's research output. Every effort has been made to ensure that content in the Research Portal does not infringe any person's rights, or applicable UK laws. If you discover content in the Research Portal that you believe breaches copyright or violates any law, please contact openaccess@qub.ac.uk. 


\title{
Paramphistomosis of ruminants: the role of free-living metacercariae
}

\section{Response from Huson et al.}

\author{
Kathryn M. Huson, Nicola A.M. Oliver and Mark W. Robinson* \\ Institute for Global Food Security, School of Biological Sciences, Queen's University \\ Belfast, 97 Lisburn Road, Belfast, Northern Ireland. \\ *Correspondence: mark.robinson@ qub.ac.uk (M.W. Robinson).
}

We are pleased that our review has stimulated further interest and discussion in this field, and welcome the additional points made by Morley [1] regarding the importance of free-living cercariae and encysted metacercariae in the lifecycle and epidemiology of paramphistome parasites.

Early acute disease, caused by immature rumen fluke in the small intestine, can cause significant morbidity and mortality to their ruminant hosts whilst the true impact of mature parasites within the rumen-reticulum, on the health and productivity of the host animal during chronic infections, is poorly understood. Therefore, further research is needed to understand paramphistomosis as an emerging threat to animal health, welfare and productivity - and this was the focus of our review. As such, the free-living and encysted metercercarial stages were not discussed in detail. However, we acknowledge the points made by Morley and agree that these stages are of importance to the study of paramphistome epidemiology. In addition, we would like to note that environmental and climatic factors will have a considerable influence on the survival of trematode cercariae and metacercariae within and between seasons, and these factors must also be considered as important influences on parasite epidemiology, particularly where any attempts to predict transmission risks for paramphistome infections are to be made. 
Changing environmental conditions have already been acknowledged as an important factor influencing the spread of parasitic diseases [2] as was mentioned in our original article [3].

\section{References}

1 Morley, N. Paramphistomosis of ruminants: the role of free- living metacercariae. Trends Parasitol. (in press)

2 van Dijk, J. et al. (2010) Climate change and infectious disease: helminthological challenges to farmed ruminants in temperate regions. Animal 4, 377-92

3 Huson, K.M. et al. (2017) Paramphistomosis of Ruminants: An Emerging Parasitic Disease in Europe. Trends Parasitol. xx, 1-9 